\title{
HOW A SLIGHT MODIFICATION OF THE BREAD-MAKING PROCEDURE FOR THE EVALUATION OF WHEAT CULTIVARS AFFECTS THE MOST IMPORTANT PROPERTIES OF BREAD (BREAD VOLUME AND BREAD CRUMB)
}

\section{KAKO NEZNATNA MODIFIKACIJA METODE PROBNOG PEČENJA KOJOM SE OCENJUJUJE PECIVOST I MEŠAVINSKA VREDNOST SORTI PŠENICE UTIČE NA NAJVAŽNIJE OSOBINE HLEBA (ZAPREMINU HLEBA I VBS)}

\author{
Dragan ŽIVANČEV*, Bojan JOCKOVIĆ*, Milan MIROSAVLJEVIĆ*, Vojislava MOMČILOVIĆ*, Novica MLADENOV*, \\ Vladimir AĆIN*, Milana PRIBIĆ** \\ *Institute of Field and Vegetable Crops, Small Grains Department, Novi Sad, Serbia Novi Sad, Serbia \\ **University of Novi Sad, Faculty of Food Technology in Novi Sad, Bul. Cara Lazara 1, 21000 Novi Sad, Serbia \\ e-mail:dragan.zivancev@ifvcns.ns.ac.rs
}

\begin{abstract}
The aim of the study was to examine how a slight modification of the standard bread-making procedure for the evaluation of wheat cultivars affects bread making properties of different quality samples, without $\alpha$-amylase activity. For that purpose, two wheat cultivars of different quality (Zvezdana and NS 40S) were examined from four different localities without diastatic activity. Standard physicochemical and rheological parameters for wheat cultivars evaluation were analysed on the eight samples. Also, bread made from flour of these samples was produced according to the standard bread-making procedure for evaluation wheat cultivars and with addition of sugar and malt according to a modified procedure. The results showed that a slight modification of the standard breadmaking procedure can affect the most important properties of bread (bread volume and bread crumb quality). The average values of both parameters were statistically higher. Additionally, statistical analyses showed that bread volume of both cultivars of differing quality was statistically higher, whereas only Zvezdana had statistically higher bread crumb quality.
\end{abstract}

Key words: bread-making procedure, wheat cultivar, breeding, amylase activity .

\section{REZIME}

Clij ovog istraživanja je bio da se ispita kako neznatna modifikacija standardne metode probnog pečenja kojom se ocenjuje pecivost $i$ mešavinska vrednost sorti pšenice utiče na osobine hleba sorti pšenice različitog kvaliteta, u kojima nije izražena $\alpha$ amilazna aktivnosti. Standardna metoda probnog pečenja kojom se ispituje pecivost i mešavinska vrednost sorti pšenice u recepturi ne sadrži sredstva za povećavanje amilazne aktivnosti što može veoma uticati na ocenu hleba i vrednost zapremine hleba kada su u uzorcima sorti pšenice utvrđene visoke vrednosti broja padanja i maksimalnog viskoziteta. Zbog toga su odabrani uzorci dve sorte pšenice različitog kvaliteta (Zvezdana i NS 40 S) sa četiri lokaliteta u kojima je utvrđena niska amilazna aktivnost. U ovih osam uzoraka su ispitani standardni fizičkohemijski i reološki pokazatelji za ocenu tehnološkog kvaliteta sorti. Hleb od brašna ovih sorti je proizveden prema standardnoj metodi probnog pečenja kojom se ocenjuje pecivost i mešavinska vrednost sorti pšenice i sa dodatkom šećera i slada prema modifikovanom postupku. Rezultati su pokazali da neznatna modifikacija standardnog postupka probnog pečenja kojom se ocenjuje pecivost $i$ mešavinska vrednost sorti pšenice može uticati na najvažnije osobine hleba (zapreminu hleba i VBS). Prosečne vrednosti oba ova pokazatelja bile su statistički više. Statistička analiza je dodatno pokazala da zapremina hleba obe sorte je statistički značajno visa, ali da samo sorta zvezdana ima statistički značajno višu vrednost VBS-a.

Ključne reči: metoda probnog pečenja, sorta pšenice, oplemenjivanje, aktivnost amilaze.

\section{INTRODUCTION}

Wheat quality differs for each participant in the chain production of wheat. The farmers' concern is how to produce high yielding wheat without impurities, and that test weight and protein content of the produced wheat are high. On the other hand, milling industry focuses on flour yield and that produced flour meets the specific requirements obtained from customers. Finally, the baking and other branches of food industry that use wheat flour as a raw material are focused on how to maintain good quality of the final product from the purchased flour. Therefore, each new cultivar has to fulfill most of the above mentioned properties. The challenge for every wheat breeder is to develop a high yielding wheat cultivar, resistant to diseases, which will satisfy the food industry demands. For that reason, it is necessary to examine the quality traits during the breeding process. Usually, the examination of quality traits starts from F4 generation: gluten strength, protein quantity, hardness, water absorption and falling number (Souza et al., 2002). Evaluation of end-use quality, bread-making potential, starts in F5 generation using a small-scale straight-dough procedure (Souza et al., 2002). Characteristic of the straight-dough procedure (long fermentation) according to the American Association of Cereal Chemists (AACC, 2000) method 10-09 is that all ingredients are mixed at the same time, the total fermentation lasts $180 \mathrm{~min}$, and ingredients are flour, water, salt, yeast, sugar, malt (dry powder), oxidation and ammonium phosphate (monobasic). Addition of malt is necessary if flour is deficient in diastatic activity. Contrary to this, classification of new cultivars in quality classes in Serbia according to Filipović et al. (2018) is still based on the internal bread making straight-dough procedure for evaluating 
wheat cultivars (Kaluđerski and Filipović, 1998). The method showed the good results in evaluation of bread-making quality of wheat cultivars with high level of inseparable impurities (Šarić et al., 2004). In this procedure only basic ingredients for bread making are used: flour, water, salt, and yeast. The problem that can be faced the breeders during the selection process when used method according to Kaluđerski and Filipović (1998) is inappropriate for evaluation of breeding materials if the examined wheat lines contain insufficient $\alpha$-amylase, indicated by Falling Number (FN) values above $400 \mathrm{~s}$. Bread made from flour of such wheat lines will characterise poor volume unless $\alpha$ amylase is added to the formulation to compensate its lack (Posner and Hibbs, 2005). Addition of exogenous $\alpha$-amylases allow production of fermentable sugars, helps yeast fermentation and production of $\mathrm{CO}_{2}$ and increases bread loaf volume and shelf life as a consequence (Eugenia Steffolani et al., 2012). Additionally, according to Filipović et al. (2005) official breadmaking procedures such as AACC and ICC are mutually differ much each other which can affect on the gained bread-making properties.

Apart from bread-making process, wheat quality also has a significant influence on the quality of the final product. According to Baardseth et al. (2000) process changes accounted for $40 \%$ of the variation in French baguette quality, whereas flour quality accounted for $16 \%$. It is well known that high protein and wet gluten content in wheat increases bread volume (Tipples and Kilborn, 1974). Also, according to Marchylo et al. (2001) loaf volume was positively correlated to gluten strength indicators such as SDS sedimentation, gluten index, Farinograph development time (Dev), Extensograph energy (En) and Alveograph work (W). The Mixolab parameters C3, C4, and C5 were significantly correlated with bread volume (Koksel et al., 2009). However, study of Salmanowicz et al. (2012) showed that higher protein and gluten contents in hard-grained wheat compared to soft-grained lines resulted in higher bread yield, whereas it did not have significant effect on loaf volume and bread crumb.

The focus of this study was to evaluate how slight modification of bread making procedure by addition of sugar and malt in internal straight-dough procedure affects bread making properties of wheat breeding material with insufficient $\alpha$-amylase. The secondary objective was to examine how flour quality affects the characteristics of bread made by two similar straight-dough procedures.

\section{MATERIAL AND METHOD}

Two wheat cultivars from different quality groups were used: Zvezdana (improver cultivar according to http://www.sorte.minpolj.gov.rs/) and NS 40S (basic cultivar according to http://www.sorte.minpolj.gov.rs/). These two cultivars were produced in 2017 at four localities in Serbia: Kikinda, Zrenjanin, Pančevo, and Sombor. FN values of six wheat samples were above $400 \mathrm{~s}$, whereas two wheat samples were above $350 \mathrm{~s}$ (Tab. 1), indicating that wheat samples were without $\alpha$-amylase activity.

Table 1. FN values of the examined wheat samples

\begin{tabular}{||c|c|c||}
\hline & Zvezdana & NS 40S \\
\hline Kikinda & 440 & 410 \\
\hline Zrenjanin & 457 & 356 \\
\hline Pančevo & 453 & 419 \\
\hline Sombor & 484 & 366 \\
\hline
\end{tabular}

Protein content (PC) (method 46-10), sedimentation value (SV) (method 56-62.01) and FN values (method 56-81.03) of wheat samples were determined according to AACC (2000) methods, and test weight was analysed according to EN ISO 7971-3:2009 standard. All analyses on grain materials were implemented in triplicate.

The wheat samples were milled on a Bühler laboratory mill MLU-202 (Uzwil, Switzerland) and flour yield was calculated for every sample. Rheological properties of the flours were determined using a Farinograph (C.W. Brabender, Duisburg, Germany) (method MSZ 6369/6) according to Hungarian Standard (1988), Extensograph (C.W. Brabender, Duisburg, Germany) (method 54-10.01) and Alveograph (Chopin, Paris, France) according to AACC (2000). Wet gluten content (WG) and gluten index (GI) were performed according to the AACC method 38-12.02. All analyses on flours were implemented in triplicate.

First bread-making procedure (WM procedure) was performed according to the internal procedure for evaluating wheat cultivars (Kaluđerski and Filipović, 1998) with 2\% salt and $2 \%$ yeast. The second bread-making procedure was a slight modification of WM procedure additionally containing 5\% sugar and $0.1 \%$ malt powder for improving amylolytic activity of flour (M procedure). Activity of $\alpha$-amylase in the malt powder was 373.26 units of $\alpha$-amylase per $g$ of malt. The bread volume (BV) was measured by displacement method with millet. Bread was analysed by sensory profiling to determine bread crumb quality by quality score (VBS) using 5 trained panellists. The lowest and the highest VBS values were 0.0 and 7.0, respectively, according to the internal method of Kaluđerski and Filipović (1998).

The data of the bread-making results were statistically analysed by two-factorial analysis of variance (ANOVA). The first factor was the cultivar, and the second factor was the bread making procedure followed by the comparison of mean values based on Tukey's multiple means comparison tests. Pearson correlation coefficients of the bread-making result and quality parameters were determined as well as principal component analysis (PCA) of quality parameters. All analyses were performed by XLSTAT-Pro software (demo version, Version 3.02, 2009).

\section{RESULTS AND DISCUSSION}

PCA analysis was used to assess whether two examined wheat cultivars (Zvezdana and NS 40S) differentiated according to value of physicochemical and rheological parameters (Fig. 1). These two cultivars can achieve the same level of yield (Mladenov et al., 2016), but their quality differentiates since Zvezdana cultivar (Aćin, 2016) possesses better values of the following quality traits: flour extraction rate, PC, WG, Farinograph water absorption (WA), Farinograph degree of softening (SD), VBS and BV in comparison to NS 40S cultivar. The PCA resulted in a clear differentiation according to quality of both groups of cultivars produced in four different locations (Kikinda, Zrenjanin, Pančevo, and Sombor). The first two principal components explained more than $75 \%$ variability of data set. Based on the first principal component explaining $60.79 \%$, NS $40 \mathrm{~S}$ was positioned on the left side of the factorial plane, and Zvezdana was positioned on the right side of the factorial plane (Fig. 1). Only five of all examined physicochemical and rheological parameters were on the left side of the factorial plane (GI, En, Extensograph Resistance (Res), Extensograph Res to Extensibility ratio (Res/E), SD and Alveograph ratio Tenacity and Extensibility $(\mathrm{P} / \mathrm{L}))$, whereas the rest were on the right side of the factorial plane. 


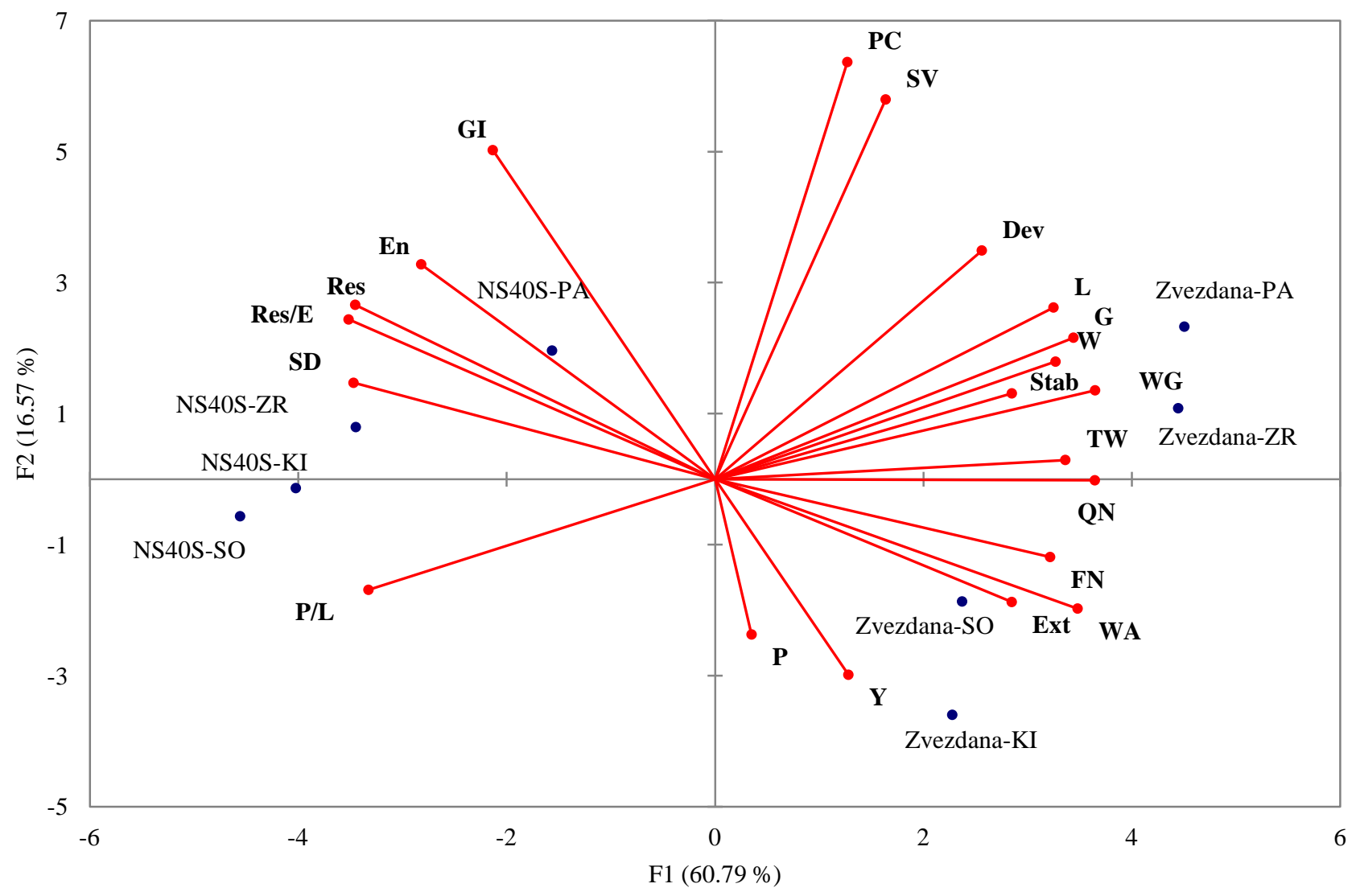

Fig. 1. PCA analysis of the first two principal components of physicochemical and rheological parameters of two wheat cultivars (Zvezdana and NS 40S)

Significant effect of the cultivar (C) factor was proven on both examined parameters of bread making procedures - VBS and bread volume (BV) (Table 1). The same significant effect was showed by the treatment $(\mathrm{T})$ factor on both examined parameters of bread making procedures. The proportion of variance of $\mathrm{C}$ factor on bread volume was much higher on $\mathrm{BV}$ (86.14) than $T$ factor on the BV (11.64). Proportion of variance of both factors on VBS was at the same level. The significant interaction $\mathrm{C} \times \mathrm{T}$ was not observed.

Table 1. ANOVA for the main analysed traits of the bread making properties

\begin{tabular}{||c|c|c|c|c|c|}
\hline \hline \multirow{2}{*}{$\begin{array}{c}\text { Source of } \\
\text { variation }\end{array}$} & \multirow{2}{*}{$\mathrm{df}$} & \multicolumn{2}{|c|}{ VBS } & \multicolumn{2}{c|}{$\mathrm{BV}$} \\
\cline { 3 - 7 } & & $\mathrm{SS}^{\mathrm{a}}$ & $\%^{\mathrm{b}}$ & $\mathrm{SS}^{\mathrm{a}}$ & $\%^{\mathrm{b}}$ \\
\hline Cultivar (C) & 1 & $456300^{* *}$ & 52.90 & $79.31^{* *}$ & 86.14 \\
\hline Treatment (T) & 1 & $403333^{* *}$ & 46.76 & $10.55^{* *}$ & 11.46 \\
\hline $\mathrm{C} \times \mathrm{T}$ & 1 & $3008^{\mathrm{ns}}$ & 0.35 & $2.21^{\mathrm{ns}}$ & 2.40 \\
\hline Error & 44 & 292025 & & 28.62 & \\
\hline
\end{tabular}

${ }^{a}$ Sum of squares and result of $F$ test

${ }^{b}$ Proportion of variance explained by the source of

variation relative to the total sum of squares

** Significant at the probability level of $p<0.01$.

${ }^{n s}$ Non significant

Results of Tukey test (Table 2) showed that BV and VBS of cultivar NS 40S obtained by WM procedure were significantly lower than Zvezdana cultivar gained by the same procedure. This confirmed that variation in raw materials quality, by using cultivars of different quality, have significant influence on quality of the final product. M procedure showed positive effect in comparison to WM procedure for both examined parameters (Table 2).

Table 2. Mean, minimum and maximum values and coefficient of variation ( $\mathrm{CV}$ ) of bread-making quality parameters by Tukey tests

\begin{tabular}{||c|c|c|c|c|c|c|c|c|c||}
\hline \hline & & \multicolumn{5}{|c|}{ VBS } & \multicolumn{5}{|c|}{ BV } \\
\hline Cultivar & & $\operatorname{mean}$ & $\min$ & $\max$ & $\begin{array}{c}\text { CV } \\
(\%)\end{array}$ & $\operatorname{mean}$ & $\min$ & $\max$ & $\begin{array}{c}\text { CV } \\
(\%)\end{array}$ \\
\hline Zvezdana & WM & $5.39^{\mathrm{b}}$ & 4.50 & 6.30 & 11.39 & $1274^{\mathrm{b}}$ & 1120 & 1360 & 5.25 \\
\hline & $\mathrm{M}$ & $6.76^{\mathrm{a}}$ & 6.50 & 7.00 & 2.52 & $1473^{\mathrm{a}}$ & 1380 & 1580 & 3.88 \\
\hline & Aver. & $6.08^{\mathrm{a}}$ & & & & $1373^{\mathrm{a}}$ & & & \\
\hline NS 40S & WM & $3.25^{\mathrm{c}}$ & 2.00 & 5.10 & 29.56 & $1095^{\mathrm{c}}$ & 960 & 1300 & 10.65 \\
\hline & $\mathrm{M}$ & $3.76^{\mathrm{c}}$ & 2.00 & 4.70 & 4.30 & $1262^{\mathrm{b}}$ & 1200 & 1360 & 4.34 \\
\hline & Aver. & $3.50^{b}$ & & & & $1178^{b}$ & & & \\
\hline Average & $\mathrm{WM}$ & $4.32^{b}$ & & & & $1184^{b}$ & & & \\
\hline & $\mathrm{M}$ & $5.26^{a}$ & & & & $1368^{a}$ & & & \\
\hline
\end{tabular}

Tukey test, different letters indicate significant difference at 0.05 probability level

This is in accordance with the study of Armero and Collar (1996) where addition of $\alpha$-Amylase increased loaf volume and decreased crumb hardness of white wheat bread. However, according to study of Hruskova et al. (2003) the effect of malt flour on the bread quality depends on flour quality. Additionally, BV of both cultivars was statistically higher by $\mathrm{M}$ procedure 


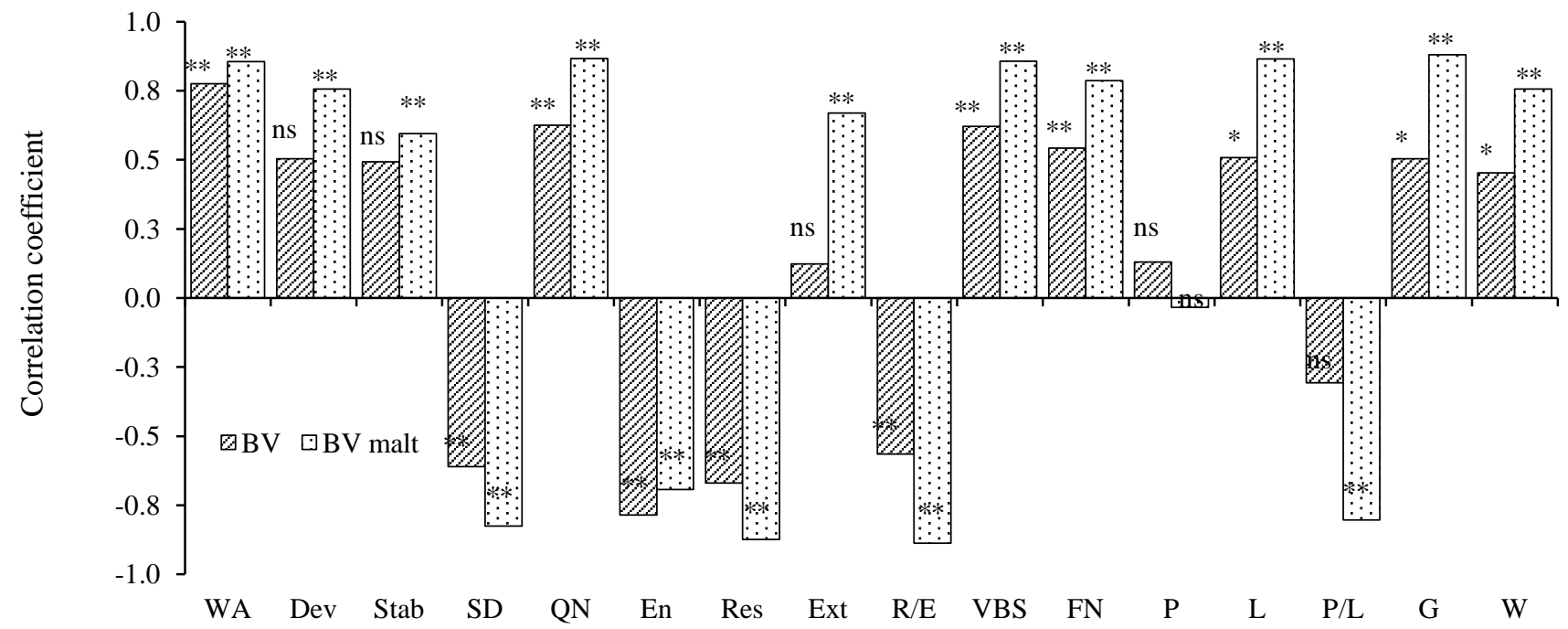

Fig.2. Correlation coefficients for BV and quality traits

(* significant at 0.01 probability level; ** significant at 0.05 probability level; $n$ s - not significant)

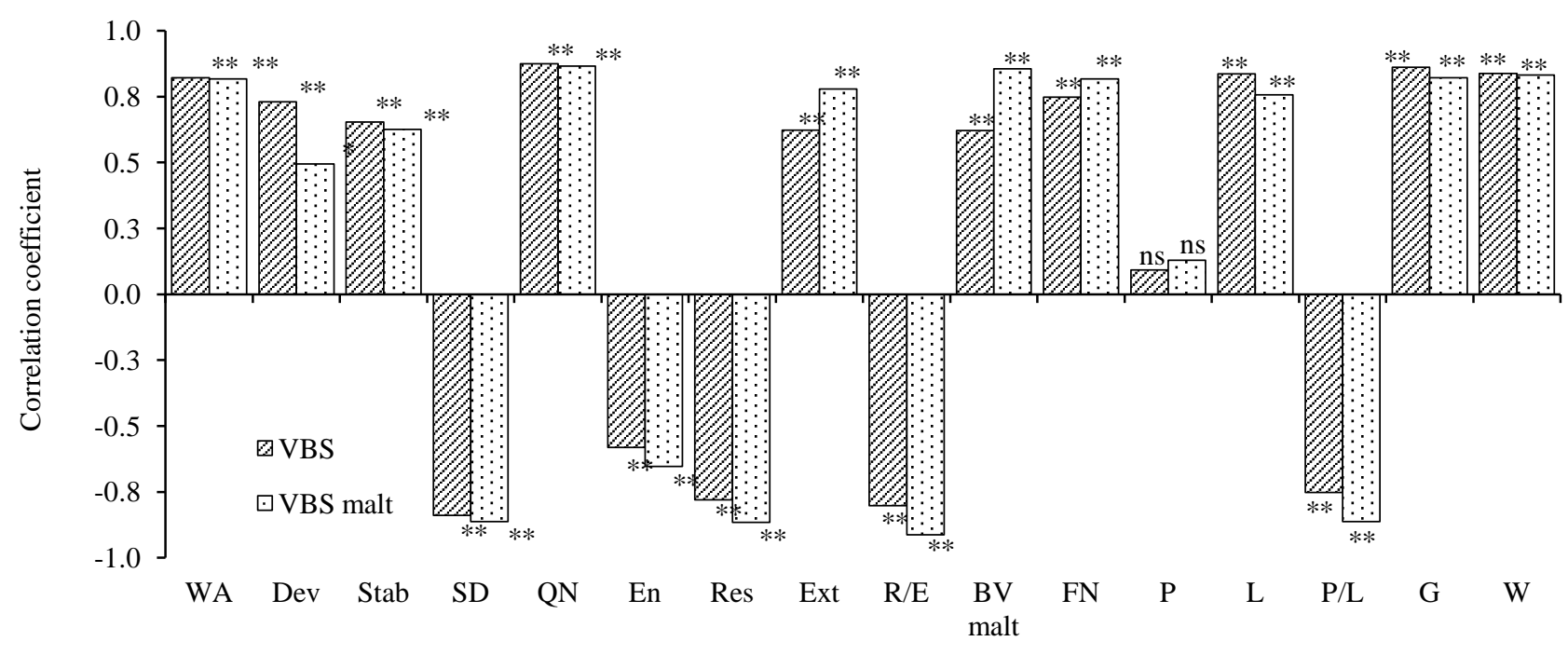

Fig. 3. Correlation coefficients for VBS and quality traits

(* significant at 0.01 probability level; ** significant at 0.05 probability level; ns - not significant)

than by WM procedure. Mean VBS values of both cultivars were higher by $\mathrm{M}$ procedure, but only Zvezdana cultivar showed significant increase. Coefficient of variation (CV) of both parameters for both examined cultivars were lower by $M$ procedure. The results indicate that slightly modification of WM procedure could be successfully used for evaluation of wheat breeding materials especially in years when late maturity $\alpha$ amylase (LMA) occurs. This phenomenon is connected with influence of environment and consequence is that one isomorph of wheat endo $\alpha$-Amylase (TaAmy1) in some wheat varieties still remains active in a small percentage in aleurone layer without sprouting (Mares and Mrva, 2008).

A final confirmation for evaluation of bread-making procedures comparison of $\mathrm{BV}$ and VBS with quality traits is presented in Figures 2 and 3. Bread-making procedures showed greater influence on BV in comparison to VBS, since Dev, Farinograph stability (Stab), Ext and $\mathrm{P} / \mathrm{L}$ gained by $\mathrm{M}$ procedure were statistically significant, whereas with WM procedure it was not case. However, these parameters did not show significant correlations with VBS. The rest of the examined correlation coefficient showed similar trends for BV and VBS.

\section{CONCLUSION}

The slight modification of the standard bread-making procedure for evaluation of wheat cultivars by addition of sugar and malt powder to the samples without diastatic activity showed statistically significant improvement of the main properties of bread (BV and VBS). This is especially important in the years when environment induces LMA phenomenon and FN values range among examined breeding line are very broad (from below 250 to above 400 s). Additionally, this modification can improve BV and VBS of cultivars with differentiating quality

ACKNOWLEDGEMENT: Authors would like to express their gratitude to Serbian Ministry of Education, Science and Technological Development which supported this article as a part of Project No. TR 31066 (2011-2019). 


\section{REFERENCES}

AACC. (2000). Approved methods of the American Association of Cereal Chemists (10th ed.). St. Paul, MN: American Association of Cereal Chemists Inc.

Aćin, V. (2016). Sowing dates and densities in a function of winter wheat yield in the long-term field trial. University of Novi Sad, Faculty of Agriculture, PhD thesis.

Armero, E., and Collar, C. (1996). Antistaling additive effects on fresh wheat bread quality. Food Science and Technology International, 2, 323-333.

Baardseth, P., Kvaal, K., Lea, P., Ellekjær, M. R., Færgestad, E. M. (2000). The Effects of Bread Making Process and Wheat Quality on French Baguettes. Journal of Cereal Science, 32, 73-87.

EN ISO 7971-3 (2009). Cereals - Determination of bulk density, called mass per hectolitre - Part 3: Routine method (ISO 79713:2009)

Filipović, J., Košutić, M., Bodroža-Solarov, M., Vučurović, V., Filipović, V., Pezo, L. (2018). Wheat variety grading by score analysis application. Journal on Processing and Energy in Agriculture, 22, 2, 85-89.

Filipović, N., Filipović, J., Šoronja Simović, D. (2005). Micro baking test - possibilities, advantages and disadvantages. Journal on Processing and Energy in Agriculture, 9, 1-2, 4245.

Hruskova, M., Svec, I., Kucerova, I. (2003). Effect of malt flour addition on the rheological properties of wheat fermented dough. Czech Journal of Food Sciences, 21, 201-218.

Hungarian Standard (1988). Lisztvizsgálati módszerek. Vízfelvevő képesség és sütőipari érték [Flour testing methods. Determination of water absorption capacity and baking quality]. MSZ 6369/6

Kaluđerski G., Filipović N. (1998). Metode ispitivanja kvaliteta žita, brašna i gotovih proizvoda [Methods for the investigation of cereals, flour and final product quality]. Faculty of Technology, Novi Sad.

Koksel, H., Kahraman, K., Sanal, T., Ozay, D. S., Dubat, A. (2009). Potential Utilization of Mixolab for Quality Evaluation of Bread Wheat Genotypes. Cereal Chemistry, 86, 5. 522-526.

Marchylo, B. A., Dexter, J. E., Clarke, F. R., Clarke, J. M., Preston, K. R. (2001). Relationships among bread-making quality, gluten strength, physical dough properties, and pasta cooking quality for some Canadian durum wheat genotypes. Canadian Journal of Plant Science, 81, 4, 611-620.

Mares, D. and Mrva, K. (2008) Late-maturity alpha-amylase: low falling number in wheat in the absence of preharvest sprouting. Journal of Cereal Science, 47, 6-17.

Mladenov, V. Banjac, B., Dimitrijević, M., Petrović, S., Latković, D., Jocković, B., Bogdanović, S. (2016). Variability of seed parameters in bread wheat cultivars. Journal on Processing and Energy in Agriculture, 20, 1, 33-35.

Posner, E.S. and Hibbs, A.N. (2005) Wheat Flour Milling. St Paul, MN, USA: American Association of Cereal Chemists Inc.

Salmanowicz, B. P., Adamski, T., Surma, M., Kaczmarek, Z., Krystkowiak, K., Kuczyńska, A., Banaszak, Z., Ługowska, B., Majcher, M., Obuchowski, W. (2012). The Relationship Between Grain Hardness, Dough Mixing Parameters and Bread-Making Quality in Winter Wheat. International Journal of Molecular Sciences, 13, 4186-4201.

Souza, E. J., Graybosch, R. A., Guttieri, M. J. (2002). Breeding Wheat for Improved Milling and Baking Quality. In A. S. Basra \& L. S. Randhawa (Eds). Quality Improvement in Field Crops Food Products (pp. 39-74.). Philadelphia, Pennsylvania, USA: Haworth Press, Inc.

Steffolani, E.M., Ribotta, P.D., Pérez, G.T. and Leóon, A.E. (2012). Combinations of glucose oxidase, $\alpha$-amylase and xylanase affect dough properties and bread quality. International Journal of Food Science and Technology, 47, 525-534.

Tipples, K. H., and Kilborn, R. H. (1974). Baking strength index and the relation of protein content to loaf volume. Canadian Journal of Plant Science, (54), 231-234.

XLSTAT-Pro (demo version, Version 3.02, 2009) software (2009). Addinsoft, Paris, France

Šarić, M., Psodorov, Đ., Živančev, D., Košutić, M. (2004), Effects of unseparable ingridients on processing quality of wheat, Journal on Processing and Energy in Agriculture, 8, 12, 31-34.

Received: 27. 06. 2019.

Accepted: 03. 12. 2019. 